\title{
Macroanatomy of the Bones of Pelvis and Hind Limb of an Asian Elephant (Elephas maximus)
}

\author{
Macroanatomía de los Huesos de la Pelvis y del Miembro \\ Posterior de un Elefante Asiático (Elephas maximus)
}

Subrata Kumar Shil; Md. Abul Quasem; Mohammad Lutfur Rahman; A. S. M. Golam Kibria; Mohi Uddin \& A. S. M. Lutful Ahasan

\begin{abstract}
SHIL, S. K.; QUASEM, M. A.; RAHMAN, M. L.; KIBRIA, A. S. M. G.; UDDIN, M. \& AHASAN, A. S. M. L. Macroanatomy of the bones of pelvis and hind limb of an Asian Elephant (Elephas maximus). Int. J. Morphol., 31(4):1473-1478, 2013.

SUMMARY: Recent excavated skeleton of an adult female Asian Elephant (Elephas maximus), died in dystokia in Bangladesh was used for macro anatomical study. Some unique morphological features of bones of hind limb were observed. Pelvic canal was more oval and the wings of ilium were wider. Rump slope was about $36^{\circ}$. Angle between femur and tibia was close to $180^{\circ}$. In Femur, the major trochanter was located at the lower level of head. Minor trochanter, fovea capitis and trochanteric ridge were absent. Supracondyloid fossa was shallow but the intercondyloid fossa was deep. Posterior surface of patella possessed a blunt vertical ridge. The articular surfaces of both tibial condyles were clearly concave. The tibia and the fibula were articulated proximally and distally with keeping a wide interosseous space. Instead of tibial tuberosity, there was an elongated triangular depression in proximal part. There were six tarsal bones arranged in three rows. The comparative size of the distal tarsal bones were III+IV > I > II. The comparative lengths of the metatarsal bones were III > II > IV > V > I. Digits I and V were the most vertical and digit III was the most horizontal. The proximal phalanx was the biggest of all.
\end{abstract}

KEY WORDS: Elephas maximus; Pelvis; Femur; Patella; Tibia; Digit.

\section{INTRODUCTION}

The elephant is the largest living terrestrial mammal. Asian elephant (Elephas maximus), the wide-ranging mega herbivore, is commonly found in 13 Asian countries including Bangladesh (Shoshani \& Eisenberg, 1982). Usually elephant is digitigrade on the forefoot (as the hippopotamus and the tapir) and semiplantigrade on the hindfoot (Mikota et al., 1994). This quadruped elephant have a similar hind limb design to bipedal human in compare to long femur, short tibia and large functionally plantigrade foot (Weissengruber et al., 2006). Moreover it exhibits similar total limb protraction and retraction angles to human (Seyfarth et al., 2003). It cannot trot or gallop due to the almost vertical orientation of the bones of the limbs like the pillars or legs of a table whereas angular position is seen in many other quadruped mammals. The elephant has also greatly expanded almost vertical pelvis like human which makes it difficult to identify the sex from the rear view. These unique morphological features are related mainly to support the enormous body weight of the animal (Weissengruber $e t$ $a l$.). So, their feet are probably the important parts of their body. Therefore, the aim of this study was to give a detailed anatomical overview of all bones of hind limbs and to contribute to current knowledge in this field.

\section{MATERIAL AND METHOD}

About 3 years ago a female elephant died of dystocia in Dulahazra Bangabondhu Safari Park of Cox's Bazar, Bangladesh. The elephant was buried in an isolated place of the safari park with aseptic measure. Recently the deep burial was excavated and bones were collected with a sequential order. The collected bones were washed under running tap water rubbing with a brush to remove the mud. Then it was dipped in detergent water for 2 hours for removing the dirt. It was dried with sunlight for seven days. For gross biometric study length, width and circumference were measured in centimeter using a metallic scale. The height of the pelvic canal (conjugate diameter) was determined from the verti- 
cal measurement between the sacral promontory to the cranial border of pelvic symphysis (Koenig \& Liebich, 2009). The width of the pelvic canal (transverse diameter) was measured from horizontal measurement between the interior surfaces of the left and right ilial shafts (Nogalski \& Mordas, 2012). Thus the pelvic inner area was estimated from the product of the height and width of the pelvic canal. Pelvic length ( $\mathrm{Hh} \mathrm{Hp}$ ) was the oblique diameter between the hip bone and the pin bone (Nogalski \& Mordas). Difference between height at hip and height at pin (Hh-Hp) was determined by deducting the height from foot to pinbone (ischial tuber) from the height from foot to hip (sacral tuber). Rump angle (a) was determined as the slope of the rump from hip to pin, taking into account pelvic length (Sin a= Hh-Hp/HP) (Nogalski \& Mordas). Width at hips was the horizontal measurement between extreme edges of hip bones and width at pins was the horizontal measurement between pin bones. Width at trochanters was measured from the horizontal measurement between the hip bones at the level of greater trochanters.

\section{RESULTS AND DISCUSSION}

Pelvic girdle. The pelvic canal in female Asian elephant was fully rounded as the conjugate and transverse diameter was same, $40 \mathrm{~cm}$ in each. Nogalski \& Mordas stated that the pelvic canal in Jersey cows was oval and laterally flattened whereas in Holstein-Friesians it was more oval in appearance. In this study rump slope was $36.15^{\circ}$ (Fig. 1) but in Jersey cattle $(n=45)$ rump slope was $9.1 \pm 2.95^{\circ}$ (Nogalski \& Mordas). The gluteal surface of os-coxae was wide and convex whereas in cattle it was concave (Getty, 1975). The ischeal arch was wider and deeper. The tuber sacrale was separated from the opposite angle by a shorter interval. The coxal tuber was projected cranially. The wings of ilium were wider and its dorsal border was convex. Width at extreme edges of hips, at ischial spine and at pins was $102 \mathrm{~cm}, 51 \mathrm{~cm}$ and $19 \mathrm{~cm}$ respectively. All three tuberosities were in equal distance. Both internal and external pelvic diameter was found larger. Pelvic inner area was $1520 \mathrm{~cm} 2$. The obturator foramen was large and oval in outline. Pelvic length and pelvic floor length was $58 \mathrm{~cm}$ and $29 \mathrm{~cm}$ respectively. Difference in height at the hip bone and the level of greater trochanter was $24 \mathrm{~cm}$ whereas difference in height at hips and pins was $34 \mathrm{~cm}$.

Femur. Femur, the longest bone, had average length of 84 $\mathrm{cm}$ and comprised of a cylindrical shaft, a proximal and a distal extremity. The circumference at proximal, middle and distal end was $38 \mathrm{~cm}, 17 \mathrm{~cm}$ and $57.5 \mathrm{~cm}$ respectively but at greater trochanter it extended to $50 \mathrm{~cm}$. It was cylindrical in the middle and prismatic distally. The cranial, medial and lateral surfaces were continuous and smooth (Fig. 2). The wide proximal extremity consisted of a head, neck and a trochanter. There was spherical smooth head without fovea capitis (Fig. 3) which was dissimilar with cattle, sheep, goat where fovea capitis was located in the middle of the head of femur (Getty). Circumference at the base of the ball was 38 $\mathrm{cm}$ whereas at constricted neck it was $32 \mathrm{~cm}$. A large tuberosity called greater trochanter was situated at the lateral aspect of the proximal end and its summit was placed almost in lower level than the head unlike with large ruminants where the greater trochanter was located at a higher level than the head. The neck was distinct as in smaller species (Dyce et al., 1996). There was absence of trochanteric minor and third trochanter in femur. The medial surface of the greater trochanter was excavated to $4 \mathrm{~cm}$ deep trochanteric fossa but no trochanteric ridge was found along the length of the bone. The distal extremity consisted of distocaudally projected two large rough condyles and a cranial trochlea. The oval shaped medial condyle was larger than the elliptical lateral condyle. Supracondyloid fossa was indistinct. The lateral and medial condyles had average length and breadth of $12 \mathrm{~cm}$ and $8 \mathrm{~cm} ; 17 \mathrm{~cm}$ and $8 \mathrm{~cm}$ respectively (Fig. 4). Between the two condyles, a broad, oblique, rough and wide inter-condyloid fossa was present as in small ruminants (Nickel et al., 1986). The length and width of inter-condyloid fossa was $7.5 \mathrm{~cm}$ and $1 \mathrm{~cm}$ respectively. The smooth wide trochlear groove had a length of $5 \mathrm{~cm}$ and breadth of $2.9 \mathrm{~cm}$. It was bounded by two parallel sagittal slightly oblique ridges - the medial and the lateral - of which the medial one was more prominent. This feature is similar to that of large ruminants but with small ruminants where both ridges are equal (Getty; Nickel et al.). In standing elephants, the angle between femur and tibia, which is close to $180^{\circ}$, differs to the half-bent posture in most mammals. A similar 'extended' knee posture occurs only in the bipedal humans (Weissengruber et al.).

Patella. The patella was elongated oval in shape, with an average length and breadth of $11 \mathrm{~cm}$ and $8 \mathrm{~cm}$ respectively (Fig. 5). The anterior surface was convex and rough while the posterior smooth concave articular surface was subdivided into a medial and a lateral facet by a blunt vertical ridge similar to human patella (Drake et al., 2010) but dissimilar with large ruminants where they have prominent vertical ridge (Getty).

Tibia and Fibula. The tibia was thicker than the fibula with a length of $48 \mathrm{~cm}$ and $47 \mathrm{~cm}$ respectively. The circumference at proximal, middle and distal end was $48 \mathrm{~cm}, 36 \mathrm{~cm}$ and 23 $\mathrm{cm}$ respectively. The tibia was articulated proximally with femur, proximal end of fibula and distally with distal end of fibula and talus like dog (Getty) and human (Drake et al.). 


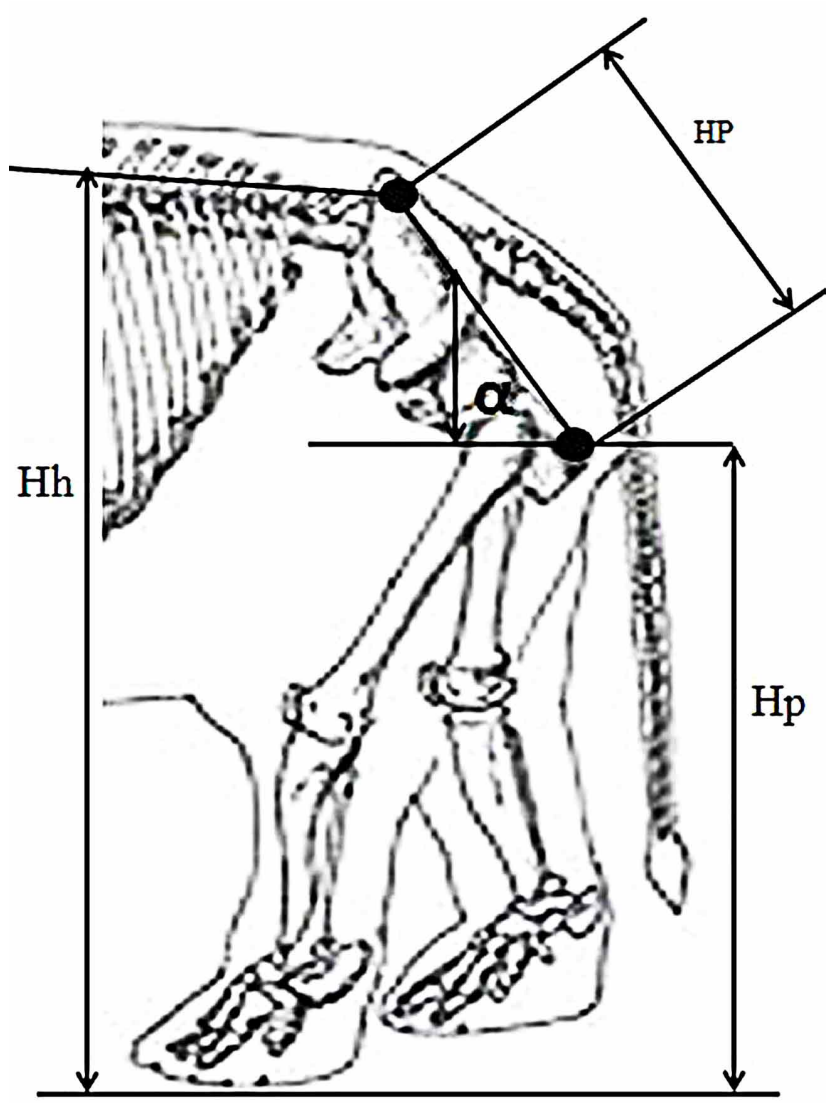

Fig. 1. Rump slope (a). Hh- height at hip (coxal tuber) Hp-height at pin (ischial tuber) $\mathrm{HP}$ - pelvic length. $\mathrm{Sin} \mathrm{a}=\mathrm{Hh}-\mathrm{Hp} / \mathrm{HP}$
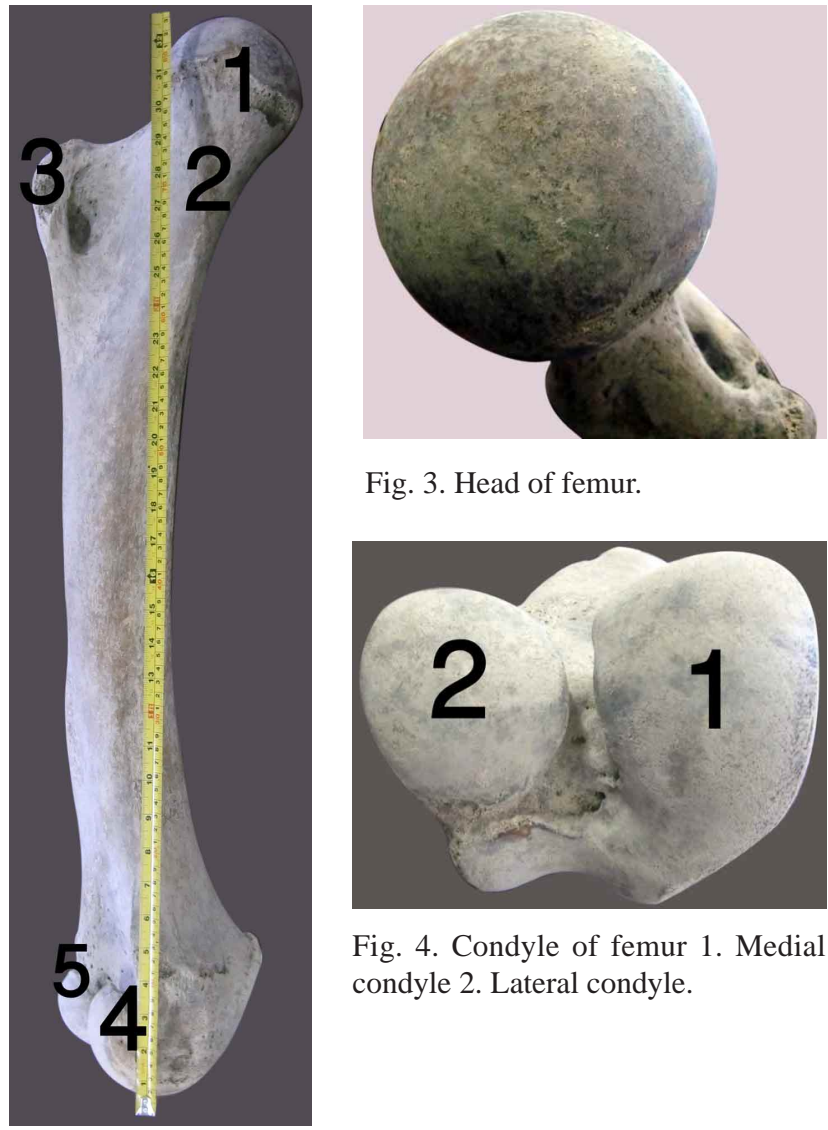

Fig. 3. Head of femur.

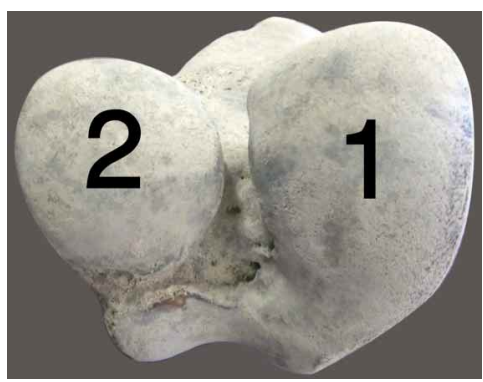

Fig. 4. Condyle of femur 1. Medial condyle 2 . Lateral condyle.
The articular surface of the proximal aspect of the tibia was roughly heart-shaped in outline when viewed proximally. The tibial tuberosity was absent and was replaced by an elongated triangular depression guarded by two oblique ridge which furnishes the attachment of patellar ligaments (Fig. 5) dissimilar with horse, ox (Getty) even human (Drake et al.). In proximal extremity, the medial condyle was larger of the two (Figs. 5 and 6). The small intercondylar eminence divides the intercondylar area into lateral and medial part. The articular surfaces of both condyles were concave, particularly centrally. The superior surface of medial condyle was oval in outline and extends laterally onto the side of medial intercondylar eminence (Fig. 6). Unlike those in most other mammals (including humans), the articular surfaces of both tibial condyles were clearly concave in elephants (Smuts \& Bezuidenhout, 1994). The distal ends of the tibia and fibula articulate with the proximal end of the talus. The articulation between the tibia and the talus beared more weight than between the smaller fibula and the talus.
Fig. 2. Femur of an Asian Elephant 1.Head 2.Neck 3. Greater trochanter 4. Lateral condyle 5. Medial condyle

Fibula, the long and slender bone, was located on the caudolateral side of the tibia. Its circumference at proximal, middle and distal end was $20 \mathrm{~cm}, 12 \mathrm{~cm}$ and $10 \mathrm{~cm}$ respectively. Its small proximal extremity was located below the level of the stiffle joint but the lower extremity was projected below the tibia that formed the lateral part of the hock joint (Fig. 7). It was attached with the tibia proximally and distally keeping a wide interrosseous space along the body. Proximal tibiofibular joint was formed between the undersurface of the lateral tibial condyle and the head of fibula and the distal tibiofibular joint was formed by the rough, convex surface of the medial side of the distal end of the fibula, and a rough concave surface on the lateral side of the tibia like human (Drake et al.).

Tarsal Bones. There were six tarsal bones arranged in three rows like the number and rows of tarsal bones of horse (Getty) but differs in only in number with human (Drake et $a l$.) where they have seven tarsal bones. The bones of the 


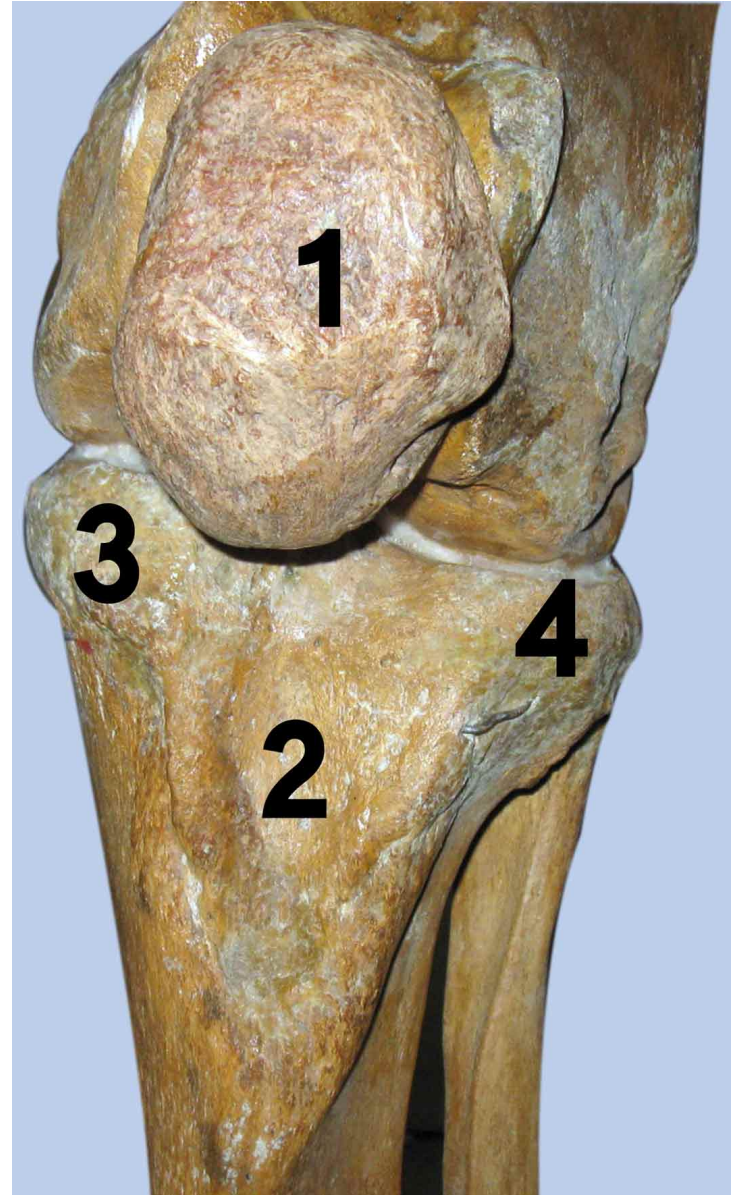

Fig. 5. Patella and tibial tuberosity 1. Patella 2. Tibial depression 3. Medial condyle of tibia 4. Lateral condyle of tibia.

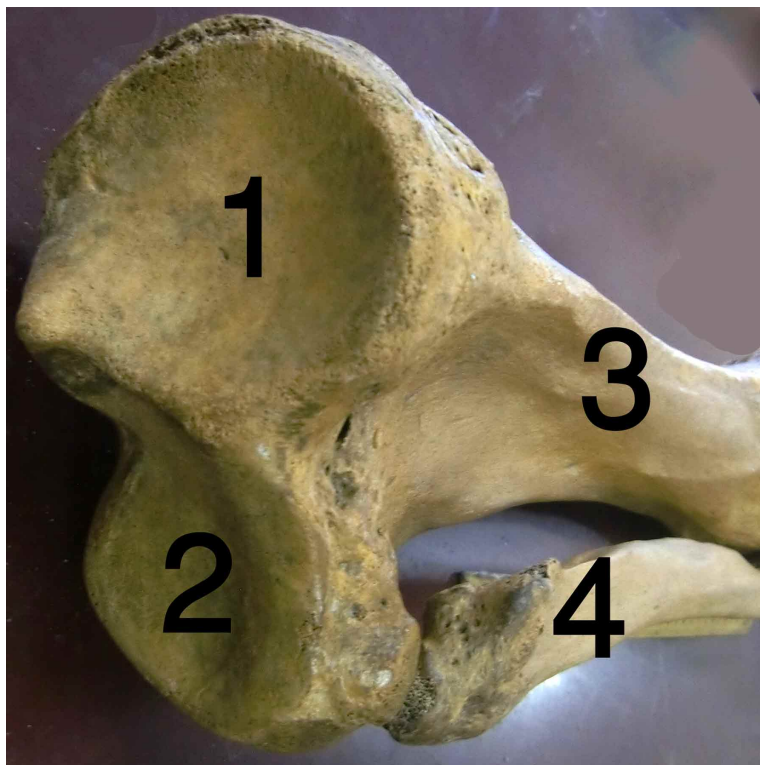

Fig. 6. Proximal articular surface of Tibia 1. Medial articular surface 2. Lateral articular surface 3. Tibia 4. Fibula

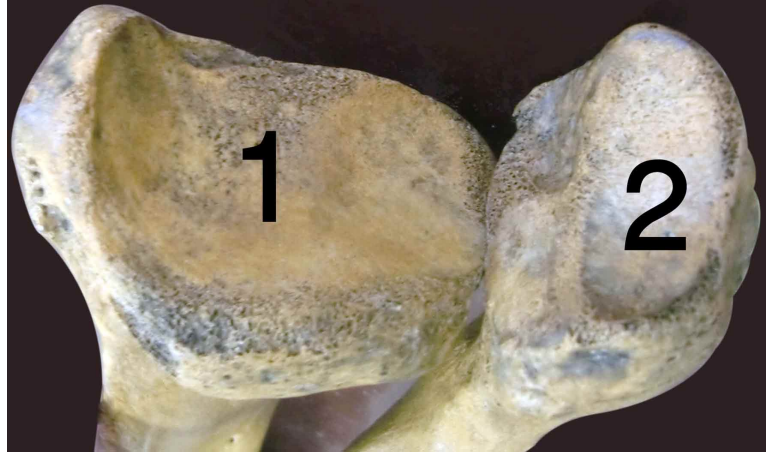

Fig. 7. Distal articular surface of Tibia and fibula 1. Distal tibial articular surface 2. Distal fibular articular surface.

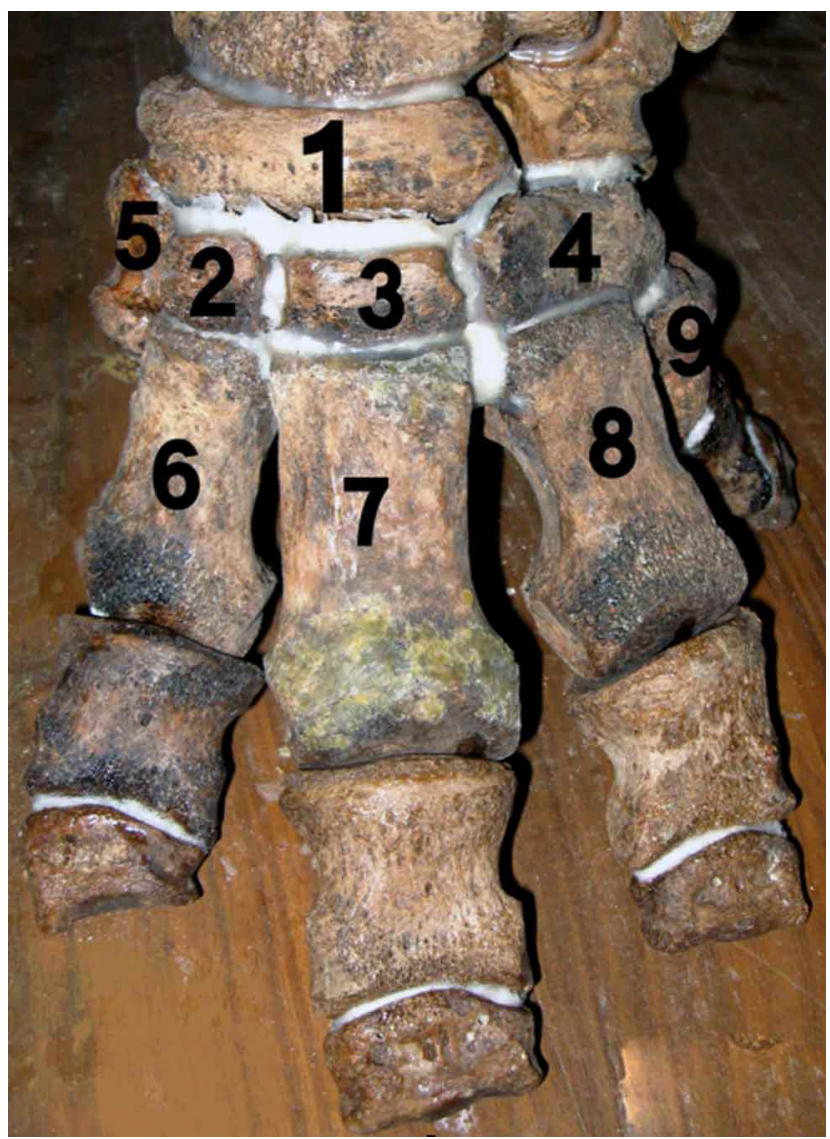

Fig. 8. Pes 1. Central tarsal bone, 2. Tarsal I, 3. Tarsal II, 4. Fused tarsal III and IV, 5. Metacarpal I, 6. Metacarpal II, 7. Metacarpal III, 8. Metacarpal IV, 9. Metacarpal V

pes are more horizontal, almost like a human wearing highheeled shoes, as the calcaneus raised from the floor by the fatty foot pad (Miller et al., 2008). The proximal row consisted of the tibial tarsal (talus) and the fibula tarsal (calcaneus) bones. Talus, the second largest of the tarsal bones, was irregular in form but there was no spiral trochlear groove as like large ruminants (Getty). It occupied 
the middle and upper part of the tarsus, supporting the tibia above, resting upon the calcaneus below. The calcaneus was the largest of the tarsal bones. It was situated at the lower and back part of the foot, serving to transmit the weight of the body to the ground. It was elongated and formed the point of the hock. It had two major parts, a caudal part that formed the calcaneal tuber (point of the hock), and a cranial extremity which bore a facet for articulation with the fused third and fourth tarsal. In middle row there was a central tarsal bone and the distal row of bones from medial to lateral consisted of tarsal I, tarsal II as well as a fused tarsal III and IV (Fig. 8). The comparative size of the distal tarsal bones were III + IV > I > II (from the largest to the smallest).

Metatarsal bones. There were five metatarsal bones lying between the tarsal bones and the phalanges. The relative size of the metatarsal bones were III $>$ II $>$ IV $>$ V $>$ I with the length $10 \mathrm{~cm}, 9.5 \mathrm{~cm}, 8.5 \mathrm{~cm}, 6 \mathrm{~cm}$ and $3 \mathrm{~cm}$ respectively (Fig. 8). Digits I and V were the most vertical and digit III was the most horizontal which supports the findings of Miller et al.

Digits. Five digits were present and each digit bearded two phalanges except first where there was only one phalanx (Fig. 8). But in African elephant digit III and IV bearded three phalanges in each (Smuts \& Bezuidenhout). Variation in number of phalanx may be due to loss of small bones during the time of collection or may be species difference. Digits three and four were larger than the others. The functional consequence of the shape of the pes is that digits II, III and IV act like the three supports of a tripod, in contrast to the more unified column of the manus (Miller et al.).

\section{CONCLUSION}

The anatomy of the bones of limbs of elephant is unique. This study will provide a better understanding of the relevant anatomy that is essential for radiographic interpretation, foot and leg disease recognition and treatment options.

\section{ACKNOWLEDGEMENTS}

The authors are grateful to the Chief Conservator of Forest, Bangladesh and the authority of Bangabandhu Sheikh Mujib Safari Park, Dulahazra, Cox's Bazar, Bangladesh for their kind cooperation.

SHIL, S. K.; QUASEM, M. A.; RAHMAN, M. L.; KIBRIA, A. S. M. G.; UDDIN, M. \& AHASAN, A. S. M. L. Macroanatomía de los huesos de la pelvis y del miembro posterior de un elefante asiático (Elephas maximus).Int. J. Morphol., 31(4):1473-1478, 2013.

RESUMEN: Fue utilizado para su estudio anatómico macrocroscópico, el esqueleto de un elefante asiático (Elephas maximus) hembra adulta, excavado recientemente y con muerte por distocia en Bangladesh. Se observaron algunas características morfológicas únicas de los huesos de los miembros posteriores. El canal pélvico era más ovalado y las alas del ilion eran más amplias. La pendiente de la rabadilla era de unos $36^{\circ}$ aproximadamente; el ángulo entre el fémur y la tibia era próximo a los $180^{\circ}$. En el fémur, el trocánter mayor se encontraba en el nivel inferior de la cabeza. El trocánter menor, la fovea capitis y cresta del trocánter estuvieron ausentes. La fosa supracondílea era superficial, mientras que la fosa intercondílea era profunda. La superficie posterior de la patela poseía una cresta vertical sobresaliente. Las superficies articulares de ambos cóndilos tibiales eran claramente cóncavas. La tibia y la fíbula se articulan proximal y distalmente, manteniendo un amplio espacio interóseo. En lugar de la tuberosidad tibial, había una depresión triangular alargada en parte proximal. Se observaron seis huesos del tarso dispuestos en tres filas. El tamaño relativo de los huesos del tarso distal eran III + IV > I > II. Las longitudes comparativas de los huesos metatarsianos fueron III > II > IV > V > I. Los dígitos I y V fueron los más verticales y el dígito III fue el más horizontal. La falange proximal fue la de mayor tamaño.

PALABRAS CLAVE: Elephas maximus; Pelvis; Femur; Patella; Tibia; Digito.

\section{REFERENCES}

Drake, R. L.; Vogl, A. W. \& Mitchell, A. W. M. Gray's Anatomy for Students. $2^{\text {nd }}$ ed. Philadelphia, Elsevier, 2010.

Dyce, K. M.; Sack, W. O. \& Wensing, C. J. G. Textbook of Veterinary Anatomy. $2^{\text {nd }}$ ed. Philadelphia, Saunders, 1996.
Getty, R. Sisson and Grossman's The Anatomy of the Domestic Animals. $5^{\text {th }}$ ed. Philadelphia, Saunders, 1975.

Konig, H. E. \& Liebich, H. G.Veterinary anatomy of domestic mammals. $4^{\text {th }}$ ed. Stuttgart, Schattauer, 2009. p.221. 
SHIL, S. K.; QUASEM, M. A.; RAHMAN, M. L.; KIBRIA, A. S. M. G.; UDDIN, M. \& AHASAN, A. S. M. L. Macroanatomy of the bones of pelvis and hind limb of an Asian Elephant (Elephas maximus). Int. J. Morphol., 31(4):1473-1478, 2013.

Nickel, R.; Schummer, A. \& Seiferle, E. The locomotor system of domestic mammals. Hamburg, Verlag Paul Parey, 1986.

Nogalski, Z. \& Mordas, W. Pelvic parameters in Holstein-Friesian and Jersey heifers in relation to their calving. Pak. Vet. J., 32(4):507-10, 2012.

Mikota, S. K.; Sargent, E. L. \& Ranglack, G. S. The musculoskeletal system. In: Mikota, S. K.; Sargent, E. L. \& Ranglack, G. S. (Ed.). Medical managment of the elephant. West Bloomfield Michigan, Indira Publishing House, 1994. pp.147-50.

Miller, C. E.; Basu, C.; Fritsch, G.; Hildebrandt, T. \& Hutchinson, J. R. Ontogenetic scaling of foot musculoskeletal anatomy in elephants. J. R. Soc. Interface, 5(21):465-75, 2008.

Seyfarth, A.; Geyer, H. \& Herr, H. Swing-leg retraction: a simple control model for stable running. J. Exp. Biol., 206:2547-55, 2003.

Shoshani, J. \& Eisenberg, J. F. Elephas maximus. Mamm. Species, 182:1-8, 1982.

Smuts, M. M. S. \& Bezuidenhout, A. J. Osteology of the pelvic limb of the African elephant. Onderstepoort J. Vet. Res., 61(1):51-66, 1994.

Weissengruber, G. E.; Fuss, F. K.; Egger, G.; Stanek, G.; Hittmair, K. M. \& Forstenpointner, G. The elephant knee joint: morphological and biomechanical considerations. J. Anat., 208(1):59-72, 2006.
Correspondence to:

Dr. Subrata Kumar Shil,

Lecturer

Department of Anatomy and Histology

Chittagong Veterinary \& Animal Sciences University

Khulshi, Chittagong

BANGLADESH

Email: skshilvet@yahoo.com

Received: 29-07-2013

Accepted: 02-11-2013 